\title{
Prevalence of Medical Students Who Use Contraceptive Methods
}

\author{
Lígia Fonseca Orlando ${ }^{1}$, Marina Telles Peramos ${ }^{1}$, \\ Letícia Margaria Peres ${ }^{1}$, Ana Beatriz Souza de Oliveria ${ }^{1}$, \\ Natalia Kokubo de Marchi ${ }^{1}$, Eduardo Vilela de Andrade ${ }^{1}$, \\ Gabriel Mendes Avilez ${ }^{1}$, Isaac Bicalho de Souza ${ }^{1}$, \\ Pedro Henrique Cruz Farina ${ }^{1}$, Pedro Rodrigues Silva ${ }^{1}$, \\ José Carlos Lopes ${ }^{2}$, Luís Cesar Fava Spessoto ${ }^{3}$, \\ Fernando Nestor Fácio $\mathrm{Jr}^{3}$
}

${ }^{1}$ Undergraduate Student, São José do Rio Preto School of Medicine (FAMERP), São José do Rio Preto, SP, Brazil

${ }^{2}$ Department of Collective Health, São José do Rio Preto School of Medicine (FAMERP), São José do Rio Preto, SP, Brazil

${ }^{3}$ Department of Urology, São José do Rio Preto School of Medicine (FAMERP), São José do Rio Preto, SP, Brazil

\begin{abstract}
The use of contraceptive methods is of extreme importance to family planning and the prevention of sexually transmitted infec tions (STIs). Such infections are transmitted through sexual (vaginal, anal and oral) contact and can be prevented with the adequate use of a condom. The present cross-sectional study was conducted with medical students at a teaching institution in the state of São Paulo, Brazil, involving the application of an online questionnaire for the analysis of the type of contraceptive method and reasons for the choice of method. The prevalence of contraceptive methods during the first sexual relation was $86.9 \%$; $7.59 \%$ of the women and $13.2 \%$ of the men who answered the questionnaire reported not using contraceptive methods during the first relation. Regarding current sexual relations, $70.2 \%$ of the students who declared an active sex life reported using a male condom and $4.3 \%$ reported using a female condom, which are important contraceptive methods that also serve for the prevention of STIs. In conclusion, the majority of medical students had initiated a sexual life and used contraceptive methods beginning with the first relation. The male condom was the most widely used among the respondents, followed by anti-conceptional methods.
\end{abstract}

Keywords: Contraceptive Methods, STI, Students, Prevalence

\section{Introduction}

Sexually transmitted infections (ISTs) are caused by viruses, bacteria and fungi. Such infections are transmitted through sexual (vaginal, anal and oral) contact and can be prevented with the adequate use of a condom. [1] Some ISTs can be controlled and treated with sexual education, medications and healthcare follow-up. The most frequent are human immunodeficiency virus (HIV) [2], syphilis [3], hepatitis B, herpes, human papilloma virus (HPV), chlamydia, trichomoniasis and gonorrhea. [1]

Several factors increase the vulnerability of individuals and population groups to ISTs. For instance, the young population is considered a vulnerable group due to characteristics such as early initiation in sexual relations, sex under the influence of alcohol and other drugs, multiple partners and inadequate condom use. [4]

According to the Health Ministry, only $56.6 \%$ of Brazilians between 15 and 24 years of age use a condom during sexual relations, despite the numerous campaigns and recommendations. [5] Some researchers believe that this is due to the fact that the younger population did not witness the AIDS epidemic in the 1980s and feels safe in terms of the current medications and improvement in quality of life among individuals with HIV. [5]

Besides this false sense of security in the young population with regards to ISTs, this age group is in a phase of changes and new experiences that can contribute to behaviors and situations of risk and vulnerability. Entering the university signifies a transition to a previously unknown scenario replete with novelties for many adolescents and young adults, including sexual experiences. Some students live alone and adopt new behaviors. Despite having a high level of schooling, knowledge on STIs and issues related to productive health is incipient in this population. [6]

The aims of the present study were to investigate the prevalence of the use of contraceptive methods among medical students, identify patterns of use and correlate patterns of use with year in the course, gender and sexual orientation.

\section{Patients and Methods}

A descriptive, cross-sectional study with a quantitative approach was conducted between August 
and September 2020. The participants were male and female students in the first to sixth years of the medical course at a higher education institution in the state of São Paulo, Brazil. Each year had 80 students, totaling 480 students. This study received approval from the institutional review board.

The data collection instrument was a questionnaire administered remotely via Google Forms and sent during one week to all students via the WhatsApp application. The questionnaire was anonymous and participation in the study was voluntary.

The questionnaire addressed data on sex, age, year of the course, sexual orientation and whether the respondent had initiated her or his sexual life. Those who answered affirmatively were asked about their first sexual relation (contraceptive choice at the time and reasons for non-use of contraceptive methods) and current sexual relations. Those currently with an active sex life with either a fixed partner or multiple partners were asked about their contraceptive choices during sexual relations and reasons for not adopting contraceptive methods. The source of information on the contraceptive method of choice was also investigated.

\section{Results}

Among the 480 students in the medical course, 133 $(27.7 \%)$ answered the questionnaire, $70(59.4 \%)$ of whom were female, $53(39.8 \%)$ were male and 10 $(0.8 \%)$ did not inform their sex. Mean age was 22.18 \pm 2.36 years (range: 18 to 31 years). Two (1.5\%) were in the sixth year of the course, six $(4.5 \%)$ were in the fifth year, $23(17.3 \%)$ were in the fourth year, $42(31.6 \%)$ were in the third year, $34(25.6 \%)$ were in the second year and $26(19.5 \%)$ were in the first year. Regarding sexual orientation $97(72.2 \%)$ were heterosexual, 25 (18.8\%) were bisexual, 10 (7.5\%) were homosexual and one $(.8 \%)$ was asexual.

The majority $(91.7 \% ; \mathrm{n}=122)$ had initiated sexual life and $106(86.9 \%)$ students used contraceptive methods during their first sexual relation. Among those who did not use contraceptive methods during their first relation, $12(13.1 \%)$ reported having trust in their partner's health.

Among the students with an active sex life, 100 $(82 \%)$ used male condoms during their first sexual relation, $59(48.9 \%)$ were protected from conception by the use of an anti-conceptional and 14 (11.5\%) practiced coitus interruptus. Other students reported the use of the Billings method, an intrauterine device and the female condom. A total of $7.59 \%$ of the women and $13.2 \%$ of the men did not use contraceptive methods during their first sexual relation. Moreover, $70 \%$ of the homosexuals did not use contraceptive method during their first sexual relation.

The main source of information on the use of contraceptive methods was a teacher and healthcare provider for the majority of students (73.4\%), followed by books, the media and school sex education class $(54.3 \%)$.

\section{Discussion}

The majority of medical students in the present study had initiated a sexual life and $86.9 \%$ of these students used contraceptive method during the first relation. In contrast, $13.1 \%$ of the respondents did not use a contraceptive method during the first relation, mainly due to trust in their partner's health. The findings indicate a good level of knowledge among the participants regarding available contraceptive methods and the importance of using such methods. However, less than half of the students used male or female condoms, indicating less protection from ISTs and suggesting that these students fear an unwanted pregnancy more than an IST [7].

Regarding the source of information on contraceptive methods, most students reported a teacher and healthcare provider, followed by books and the media. This reveals the importance of these professionals and the media in the rapid dissemination of information. However, the media does not always reflect scientific evidence. Moreover, the search for information on the internet has replaced counseling and appointments with professionals in contemporary society [8].

Analyzing the use of contraceptive methods among homosexual students (women and men), $70 \%$ did not use any method or protection from ISTs during the first relation. This may be due to the lack of a risk of pregnancy and the lack of an appropriate method for sexual relations.

Among the students with an active sex life, $3.7 \%$ of the men did not use contraceptive methods, with equal distribution between heterosexuals and homosexuals, and $5 \%$ of the women did not use a contraceptive method, the majority of whom were homosexual. Based on these findings, women tend to protect themselves more and use contraceptive methods more than men. This information is worrisome, as unwanted pregnancy is not the only risk of unprotected sex. ISTs can be transmitted in any type of sexual relation [9].

\section{Conclusion}

The majority of medical students had initiated a sexual life and used contraceptive methods beginning with the first relation. The male condom was the most widely used among the respondents, followed by anti-conceptional methods. 


\section{Acknowledgments}

The authors thank Professor José Carlos Lopes for the idea and proposal.

\section{References}

1. Ministério da Saúde. Infecções Sexualmente Transmissíveis (IST). Gov.br, 2020. Disponível em https://www.gov.br/saude/pt-br/assuntos/saude-de-a-a-z1/i/infeccoes-sexualmente-transmissiveis-ist. Acesso em: 02 fev 2021 https://doi.org/10.48140/digitaleditora.2021.005.7

2. Secretaria de Vigilância em Saúde. Ministério da Saúde. Boletim Epidemiológico de HIV e Aids. Número Especial. Brasília. Dez 2020 https://doi.org/10.26512/2016.02.d.20359

3. Portal PEBMED. Sífilis: aumento mais de $4000 \%$. Pebmed.com.br, 2019. Disponível em: https://pebmed.com.br/sifilis -aumento-mais-de-4-000-doscasos-no-brasil/ Acesso em: 02 fev 2021 https://doi.org/10.22533/at.ed.1512101021

4. Gutierrez, E.; Pinto, V.; Basso, C.; Spiassi, A. : Fatores associados ao uso de preservativo em jovens - inquérito de base populacional. Rev. bras. epidemiol. vol.22, São Paulo, 2019. Epub Apr 25, 2019 https://doi.org/10.1590/1980549720190034

5. Portal PEBMED. Segundo Ministério da Saúde, quase metade dos brasileiros não usa caisinha. Pebmed.com.br, 2018. Disponível em: https://pebmed.com.br/segundoministerio-da-saude-quase-metade-dos-jovens-brasileirosnao-usa-camisinha/ Acesso em: 02 fev 2021 https://doi.org/10.51723/ccs.v28i03/04.272

6. Spindola, T. ; Araújo, A.; Brochado, E. ; Marinho D.; Martins, E. : Práticas sexuais e o comportamento de jovens universitários frente à prevenção de infecções sexualmente transmissíveis. Rev. Eletrônica Trimestral de Enfermaria. Abril

https://doi.org/10.6018/eglobal.382061

7. Pareja Franchi, G. ., Telles Peramos, M. ., dos Santos, E. R. ., Aparecido Brienze, S. L. ., César André, J. ., \& de Abreu Lima, A. R. . (2021). Correlação entre educação sexual e prevenção de gravidez e de doenças sexualmente transmissíveis. Saúde Coletiva (Barueri), 11(66), 6465-6482. https://doi.org/10.36489/saudecoletiva.2021v11i66p64656482

https://doi.org/10.36489/saudecoletiva.2021v11i66p64656482
8. Rodrigues, A. C. M., Lima, G. C., Coelho, L. O., Silva, L. O. Oliveira, A. S., \& Torres, T. G. (2017). A internet como fonte de informação em saúde de pacientes. Revi Educ Saúde, 5. https://doi.org/10.29237/2358-9868.2019v 7i1.p81-89

9. Knight, D. A., \& Jarrett, D. (2017). Preventive health care for women who have sex with women. American family physician, 95(5), 314-321.

10. Ministério da Saúde. Infecções Sexualmente Transmissíveis (IST). Gov.br, 2020. Disponível em https://www.gov.br/saude/pt-br/assuntos/saude-de-a-a-z1/i/infeccoes-sexualmente-transmissiveis-ist. Acesso em: 02 fev 2021

11. Secretaria de Vigilância em Saúde. Ministério da Saúde. Boletim Epidemiológico de HIV e Aids. Número Especial. Brasília. Dez 2020

12. Portal PEBMED. Sífilis: aumento mais de $4000 \%$. Pebmed.com.br, 2019. Disponível em: https://pebmed.com.br/sifilis-aumento-mais-de-4-000-doscasos-no-brasil/ Acesso em: 02 fev 2021

13. Gutierrez, E.; Pinto, V.; Basso, C.; Spiassi, A. : Fatores associados ao uso de preservativo em jovens - inquérito de base populacional. Rev. bras. epidemiol. vol.22, São Paulo, 2019. Epub Apr 25, 2019

14. Portal PEBMED. Segundo Ministério da Saúde, quase metade dos brasileiros não usa caisinha. Pebmed.combr 2018. Disponível em: https://pebmed.com.br/segundoministerio-da-saude-quase-metade-dos-jovens-brasileirosnao-usa-camisinha/ Acesso em: 02 fev 2021

15. Spindola, T. ; Araújo, A.; Brochado, E. ; Marinho D.; Martins, E. : Práticas sexuais e o comportamento de jovens universitários frente à prevenção de infecções sexualmente transmissíveis. Rev. Eletrônica Trimestral de Enfermaria. Abril 2020

16. Pareja Franchi, G. ., Telles Peramos, M. ., dos Santos, E. R. ., Aparecido Brienze, S. L. ., César André, J. ., \& de Abreu Lima, A. R. . (2021). Correlação entre educação sexual e prevenção de gravidez e de doenças sexualmente transmissíveis. Saúde Coletiva (Barueri), 11(66), 6465-6482. https://doi.org/10.36489/saudecoletiva.2021v11i66p64656482

17. Rodrigues, A. C. M., Lima, G. C., Coelho, L. O., Silva, L. O., Oliveira, A. S., \& Torres, T. G. (2017). A internet como fonte de informação em saúde de pacientes. Revi Educ Saúde, 5.

18. Knight, D. A., \& Jarrett, D. (2017). Preventive health care for women who have sex with women. American family physician, 95(5), 